\title{
BLOOD PROLACTIN IN THE MALE LAMB FROM BIRTH TO PUBERTY
}

\author{
J. P. RAVAULT* AND M. COUROT \\ Station de Physiologie de la Reproduction, I.N.R.A., \\ 37380 Nouzilly, France
}

(Received 8th Fuly 1974)

Prolactin has been detected in the peripheral blood plasma of adult male mammals. Basic levels of 20 to $30 \mathrm{ng} / \mathrm{ml}$ plasma have been detected in the male rat (Amenori, Chen \& Meites, 1970). These basic levels can reach $50 \mathrm{ng} / \mathrm{ml}$ in the ram (Davis, Reichert \& Niswender, 1971), 80 to $200 \mathrm{ng} / \mathrm{ml}$ in the male goat (Hart, 1973; Buttle, 1974) and 30 to $40 \mathrm{ng} / \mathrm{ml}$ in the bull (Oxender, Hafs \& Ingalls, 1972). The rolle of prolactin in the male, however, is not well known.

This paper deals with the evolution of prolactin in the peripheral blood plasma of nine ram lambs (Ille de France) during the first 17 weeks after birth. The period studied covered the onset of spermatogenesis (Courot, 1962). The animals, born at the end of September, were bred in natural conditions and were weaned progressively when 100 days old. Weekly morning blood samples were collected from the jugular vein, the first one being collected 1 week after birth. After cold centrifugation, all plasmas were kept frozen until they were analysed simultaneously for their prolactin concentration by specific radioimmunoassay according to the method described by Kann (1971). The results were expressed in $\mathrm{ng}$ prolactin $\mathrm{PS} 6 / \mathrm{ml}$ plasma. Table 1 shows the mean prolactin concentrations and the body weights of the nine lambs and Text-fig. 1 indicates the individual prolactin concentration values in the same animals over the same period.

Prolactin was present in the peripheral blood 1 week after birth.

In three lambs (Nos 49, 58 and 68), there was a slight increase to 38 to $50 \mathrm{ng}$ PS6 $/ \mathrm{ml}$ plasma for 1 or 2 weeks after birth, but the level of prolactin remained at a basic level in the six other lambs. A sharp increase in prolactin level occurred 10 weeks (Nos 49, 58 and 79), 11 weeks (Nos 62 and 68) or 12 weeks (Nos $69,72,76$ and 77) after birth and reached a maximum value in 1 or 2 weeks, with individual values as high as $140 \mathrm{ng}$ PS6/ml plasma (No. 79). The prolactin level then fell rapidly within 1 or 2 weeks to basic levels.

The first peak, which occurred only in three lambs, and the small variations seen in the other animals, might have been due to stresses which are known to induce a prolactin discharge (Raud, Kiddy \& Odell, 1971). Such an hypothesis cannot, however, explain the sharp peak encountered in all the animals around 80 days after birth, since they were inured to venepuncture, and the peak occurred before the stress of weaning. The subsequent rapid decrease of prolactin to basal levels would also appear to discount any stress effect. In the

* Present address: Laboratoire de Physiologie Comparée, Faculté des Sciences, 37200 Tours, France. 
bull (Karg \& Schams, 1974), in the male goat (Buttle, 1974) and in the ram (Pelletier, 1973; J. P. Ravault and M. Courot, unpublished observation), high levels of prolactin are found during long daylight periods (March to

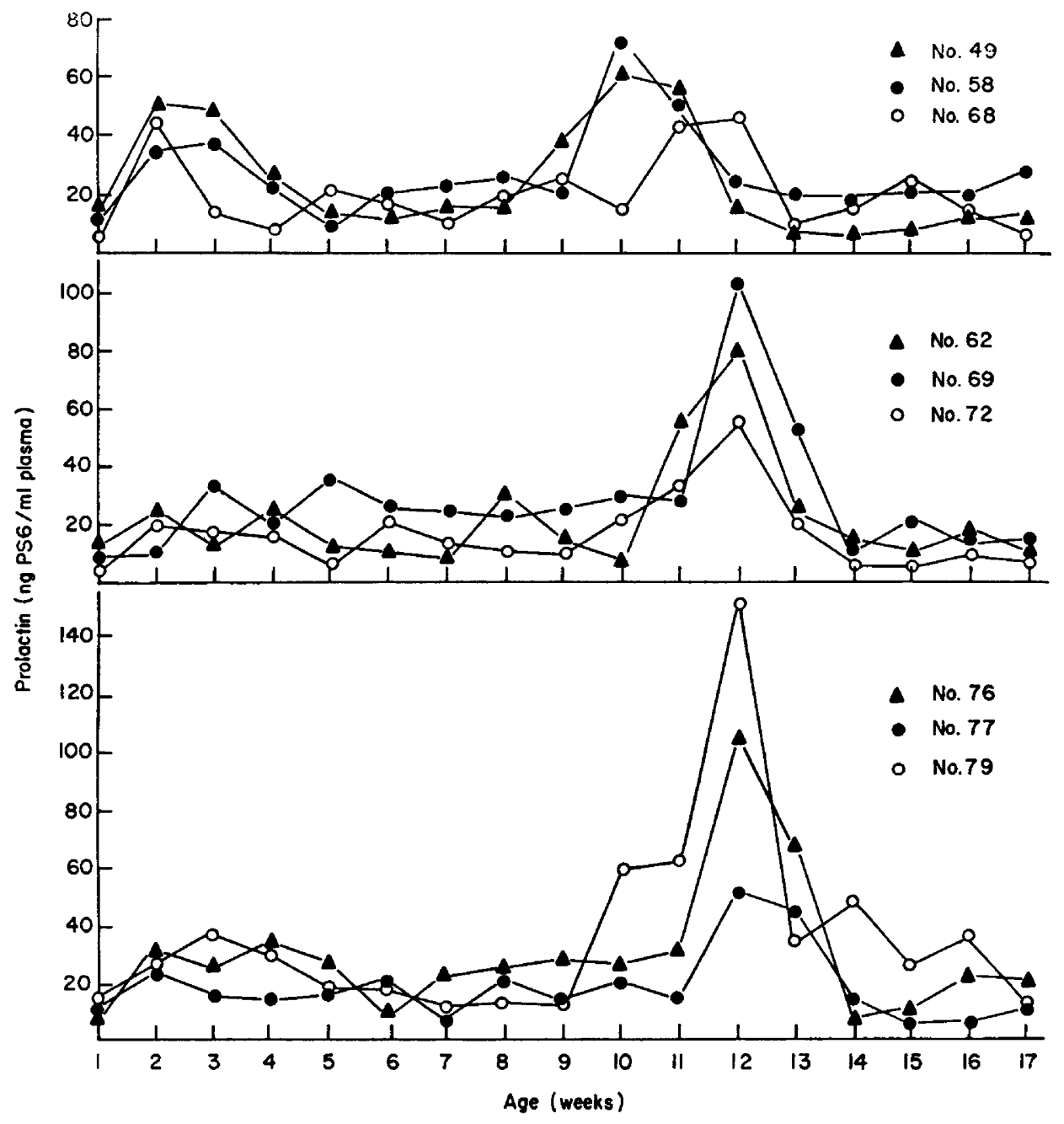

Text-Fig. 1. Prolactin levels in the peripheral blood plasma of each of nine Ile-deFrance ram lambs from 1 to 17 weeks after birth.

September) and low levels during short daylight periods (October to February). Consistently low values occurred in November and December and these results indicate that the prolactin peak is not light-dependent.

The rapid increase in prolactin was present in all animals and occurred simultaneously with the beginning of a rapid increase in the weight of the testes and in spermatogenic activity. While the duration of the prolactin peak was very brief, the maximum corresponding to a testicular weight of 50 to $60 \mathrm{~g}$ (calculated by a linear regression-Courot, 1971), the growth of the gonads continued. This evolution of prolactin was completely independent of blood LH and 
testosterone levels checked in the same animals (Courot, 1971; Cotta, Terqui \& Courot, 1974). The prolactin secretion during postnatal development in the lamb differs from that in the rat in which the prolactin secretion in the peripheral blood increases with age (Negro-Vilar, Krulich \& McCann, 1973; Döhler \& Wuttke, 1974).

In conclusion, these results show that prolactin secretion in ram lambs occurs during a well-defined time in the growth of the testes and the establishment of spermatogenesis.

Thanks are due to Dr G. Kann for making available the material for the radioimmunoassay of prolactin and to Miss Claudine Pisselet for her technical assistance. This work was supported by a grant of the Délégation Générale à la Recherche Scientifique et Technique, No. 71-7-3021. We thank the National Institute of Health (Bethesda) for the gift of sheep prolactin.

\section{REFERENCES}

Amenori, Y., Ghen, G. L. \& Mzites, J. (1970) Serum prolactin levels in rats during different reproductive states. Endocrinology, 86, 506-510.

ButrLE, H. L. (1974) Seasonal variation of prolactin in plasma of male goats. F. Reprod. Fert. 37, 95-99.

CotTA, Y., TERQUI, M. \& Gourot, M. (1974) Testostérone plasmatique chez l'agneau de la naissance à la puberté. C. r. hebd. Séanc. Acad. Sci., Paris, (in press).

Courot, M. (1962) Développement du testicule chez l'agneau. Etablissement de la spermatogénèse. Annls Biol. anim. biochim. Biophys. 2, 25-42.

Courot, M. (1971) Etablissement de la spermatogénèse chez l'agneau. Etude expérimentale de son contrôle gonadotrope. Thèse Doct. Sci., GNRS AO6317. 1-200.

Davis, S. L., ReICHERT, L. E. \& Niswender, G. D. (1971) Serum levels of prolactin in sheep as measured by radioimmunoassay. Biol. Reprod. 4, 145-153.

DöHLER, K. D. \& Wuttke, W. (1974) Serum LH, FSH, prolactin and progesterone from birth to puberty in female and male rats. Endocrinology, 94, 1003-1008.

HART, I. G. (1973) Basal levels of prolactin in goat blood measured throughout a 24-h period by a rapid double antibody phase radioimmunoassay. F. Dairy Res. 40, 235-245.

KanN, G. (1971) Dosage radioimmunologique de la prolactine plasmatique chez les ovins. C. r. hebd. Séanc. Acad. Sci., Paris, 272, 2808-2811.

Karg, H. \& Schams, O. (1974) Prolactin release in cattle. F. Reprod. Fert. 39, 463-472.

Negro-Vilar, A., Krulich, L. \& McGanN, S. M. (1973) Changes in serum prolactin and gonadotrophins during sexual development of the male rat. Endocrinology, 93, 660-664.

Oxender, W. D., Hafs, H. D. \& InGalls, W. G. (1972) Serum growth hormone, LH and prolactin in the bovine fetus and neonate. F. Anim. Sci. 35, 56-61.

Pelletier, J. (1973) Evidence for photoperiodic control of prolactin release in rams. F. Reprod. Fert. $35,143-147$.

Raud, H. A., KidDY, C. A. \& Odeil, W. D. (1971) The effect of stress upon the determination of serum prolactin by radioimmunoassay. Proc. Soc. exp. Biol. Med. 136, 689 693. 